Jurnal ECOTIPE, Vol. 7, No.2, Oktober 2020, Hal. 117-126

p-ISSN 2355-5068, e-ISSN 2622-4852

Akreditasi Kemenristekdikti (SINTA 4), SK. No.10/E/KPT/2019

DOI: 10.33019/jurnalecotipe.v7i2.1892

\title{
Implementasi Aplikasi Styins Home pada Smart Home Security Menggunakan Real-Time Database Firebase
}

\author{
Agni Andhini ${ }^{1}$, Ibrahim ${ }^{2}$, Yuliarman Saragih ${ }^{3}$ \\ Program Studi Teknik Elektro, Universitas Singaperbangsa Karawang ${ }^{1}$ \\ Program Studi Teknik Elektro, Universitas Singaperbangsa Karawang ${ }^{2}$ \\ Program Studi Teknik Elektro, Universitas Singaperbangsa Karawang ${ }^{3}$ \\ *agniandhini16006@student.unsika.ac.id', ibra.lammada@gmail.com², yuliarman@gmail.com ${ }^{3}$
}

\begin{abstract}
The IoT-based Styins Home (Security System Interface Smart Home) application system has been implemented. This study aims to build a control system and monitoring of security conditions of remote home devices in real-time so as to prevent losses due to negligence in maintaining home security conditions. Application features include camera streaming, smart light, smart fan and detection gas along with notification alerts. This application utilizes the Firebase real-time database as a database management service and Android Studio software. The research method in designing application systems uses the waterfall model. The data from the test results of the delay value according to the TIPHON standard include very good quality delay categories, namely $7.1 \mathrm{~ms}$ on $240 \mathrm{kbps}$ camera streaming and moderate category delay quality, namely 425.08 ms on smart light, smart fan and gas detection on firebase $32 \mathrm{kbps}$ while the result data testing the percentage value of the highest throughput percentage with medium network quality, namely $40.80 \%$ on 240 kbps camera streaming, while other throughput percentage values have poor network quality.
\end{abstract}

Keywords: Delay, Real-Time Database, Styins Home, Throughput

\section{INTISARI}

Telah dilakukan implementasi sistem aplikasi Styins Home (Security System Interface Smart Home) berbasis IoT. Penelitian ini bertujuan membangun sistem kontrol dan monitoring kondisi keamanan perangkat rumah jarak jauh secara real-time sehingga mencegah kerugian akibat kelalaian dalam penjagaan kondisi keamanan rumah. Fitur aplikasi meliputi streaming kamera, smart light, smart fan dan detection gas dilengkapi peringatan notifikasi. Aplikasi ini memanfaatkan real-time database firebase sebagai layanan pengelola database dan software android studio. Metode penelitian dalam perancangan sistem aplikasi menggunakan model waterfall. Data hasil pengujian nilai delay menurut standarisasi TIPHON termasuk kualitas delay kategori sangat bagus yaitu 7,1 ms pada streaming kamera $240 \mathrm{kbps}$ dan kualitas delay kategori sedang yaitu 425,08 ms pada smart light, smart fan dan detection gas di firebase $32 \mathrm{kbps}$ sedangkan data hasil pengujian nilai persentasi throughput tertinggi dengan kualitas jaringan sedang yaitu 40,80\% pada streaming kamera 240 kbps sedangkan nilai persentasi throughput lainnya memiliki kualitas jaringan yang buruk.

Kata kunci: Delay, Real-Time Database, Styins Home, Throughput

\section{PENDAHULUAN}

Peralatan rumah pintar merupakan kebutuhan sekunder yang membuat aktivitas manusia menjadi lebih praktis dan juga efektif. Disamping itu seiring dengan kelalaian yang dilakukan oleh pemilik rumah dalam menjaga keamanan sehingga menyebabkan kerugian serta pemborosan dalam penggunaan peralatan listrik yang berlebihan dan tidak terkontrol.
Dengan adanya perkembangan ilmu teknologi dan pengetahuan, tercipta sebuah aplikasi rumah pintar (smart home) yaitu berfungsi untuk memantau ataupun mengontrol dari segi aspek keamanan rumah dan perangkat rumah dengan jarak jauh menggunakan smartphone.

Penelitian sebelumnya dilakukan oleh Atep Septian, dkk. (2019) dengan judul penelitian sebelumnya kontrol lampu secara wireless berbasis 
Jurnal ECOTIPE, Vol. 7, No.2, Oktober 2020, Hal. 117-126

p-ISSN 2355-5068, e-ISSN 2622-4852

Akreditasi Kemenristekdikti (SINTA 4), SK. No.10/E/KPT/2019

DOI: 10.33019/jurnalecotipe.v7i2.1892

Arduino Uno kontrol lampu menggunakan MYSQL sebagai database dan aplikasi berbasis web platform blink [1]. Mustaqim, Abi Sabila, Kurnianto, dkk (2020) dengan judul penelitian implementasi teknologi internet of things pada sistem pemantauan kebocoran gas LPG dan kebakaran menggunakan database pada google firebase [2]. kelebihan dari penelitian menggunakan firebase sebagai layanan backend, kekurangan dari 2 referensi ini belum adanya sistem keamanan dan pengontrol perangkat rumah untuk mengatasi masalah pemilik rumah secara menyeluruh seperti mengetahui kondisi keamanan sekitar rumah, dapat mengontrol beberapa lampu, meninggalkan ruangan terlalu lama dengan keadaan kipas menyala ataupun pemilik rumah lupa untuk melepaskan regulator gas sehingga dapat berpotensi kebakaran rumah memanfaatkan android studio sebagai platform membangun aplikasi [3].

Untuk mengatasi permasalahan berdasarkan kekurangan dari 2 referensi yang telah disebutkan diatas, dibuatlah sebuah rancangan sistem berupa sebuah aplikasi yang dapat mengetahui kondisi keamanan dan kontrol perangkat rumah setiap waktu dengan jarak yang jauh melalui smartphone menggunakan konsep Internet of Things (IoT) [4]. Layanan konsep IoT yang saya gunakan untuk pembuatan aplikasi ini adalah firebase. Produk aplikasi ini dinamakan aplikasi styins home. Firebase adalah sebuah layanan infrastuktur backend-as-a-servise (BaaS) yang diakuisisi oleh google pada oktober 2014 silam [5]. Firebase pada aplikasi ini berfungsi menyatukan 3 data yang dikirimkan oleh mikrokontroler yang berbeda dan mengolahnya agar dapat memonitoring alat elektronik secara real-time dengan memanfaatkan real-time database firebase [6]. Real-time database firebase dapat mengimplementasi seperti kontrol lampu, kontrol smartfan dan memantau keadaan suhu dan kelembaban ruangan sehingga dapat mengatur secara otomatis kecepatan putaran smart fan dan implementasi monitoring kadar gas dalam ruangan dapur sehingga berfungsi untuk mengaktifkan exhaust fan ketika telah melewati pengaturan kadar $>200$ untuk asap dan $>300$ untuk gas. Sedangkan pada kamera mengakses data tidak melalui firebase tetapi melalui akses data berupa IP yang dimiliki oleh ESP32-Cam berfungsi menampilkan rekaman siaran langsung melalui aplikasi. Hal ini berfungsi untuk membuat efisien dalam pemanfaatan waktu, keamanan dan kenyamanan pemilik rumah karena dapat memantau dan mengontrol keamanan dan perangkat rumah apabila sedang meninggalkan rumah dengan waktu yang lama menggunakan 1 aplikasi.

\section{LANDASAN TEORI}

\section{A. Bandwidth}

Bandwidth merupakan kapasitas luas maksimal cakupan suatu jaringan untuk melakukan proses pengiriman dan penerimaan data dari sebuah titik ke titik lain dalam jangka waktu tertentu yang dihitung dalam satuan waktu bit per second (bps) [7]. Besarnya alokasi bandwidth sangat berpengaruh untuk menentukan bandwidth mana yang lebih kuat seperti penggunaan antena multiband pada sebuah sistem radio frequensi (RF) dimaksudkan untuk meningkatkan efisiensi sistem tersebut secara ekonomi yang dapat memberikan efek peningkatan kapasistas dengan coverage yang lebih luas [8].

B. Real-time database

Real-time database merupakan sebuah layanan database NoSQL sehingga aplikasi ini dapat digunakan oleh banyak client dengan data diterima secara realtime. Penggunaan fitur real-time database ini membangun sebuah sistem bersifat responsive dengan didukung API real-time database yang dirancang mampu menjalankan operasi sistem dengan cepat [6],[9].

\section{NodeMCU ESP8266}

NodeMCU ESP8266 merupakan sebuah modul wifi perangkat tambahan mikrokontroler berfungsi terkoneksi TCP (Transmission Control Protokol) secara langsung [10]. Mikrokontroller adalah suatu komponen elektronika digital yang memiliki masukan, keluaran serta kendali, cara kerja mikrokontroler sebenarnya membaca dan menulis data [11].

\section{METODE PENELITIAN}

Penelitian perancangan sistem aplikasi styins home dilakukan beberapa tahapan, seperti: implementasi perancangan sistem styins home, perhitungan delay dan perhitungan throughput.

\section{A. Perancangan Sistem Keseluruhan}


Jurnal ECOTIPE, Vol. 7, No.2, Oktober 2020, Hal. 117-126

p-ISSN 2355-5068, e-ISSN 2622-4852

Akreditasi Kemenristekdikti (SINTA 4), SK. No.10/E/KPT/2019

DOI: 10.33019/jurnalecotipe.v7i2.1892

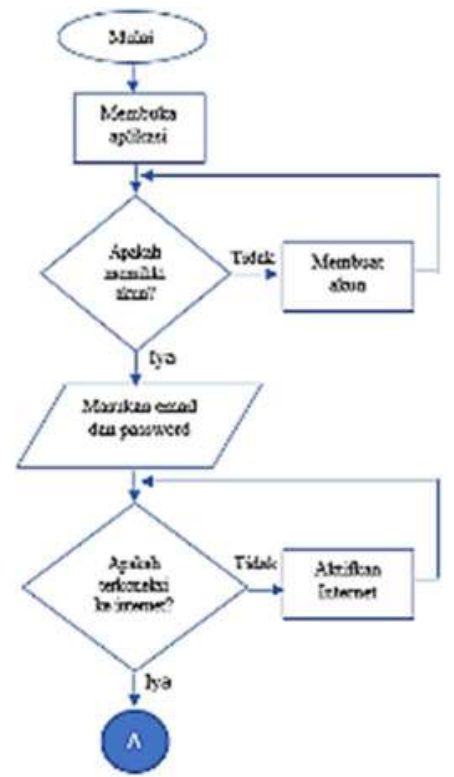

Gambar 1. Flowchart Login Aplikasi

Berdasarkan Gambar 1 dijelaskan bahwa pada saat memasuki aplikasi styins home akan dilakukan autentification akun dengan verifikasi email dan password. Jika pengguna belum memiliki akun disarankan untuk segera melakukan registrasi akun. Setelah memiliki akun, pengguna harus memastikan smartphone terkoneksi dengan jaringan internet yang berfungsi untuk menghubungkan perangkat lunak dengan perangkat keras.

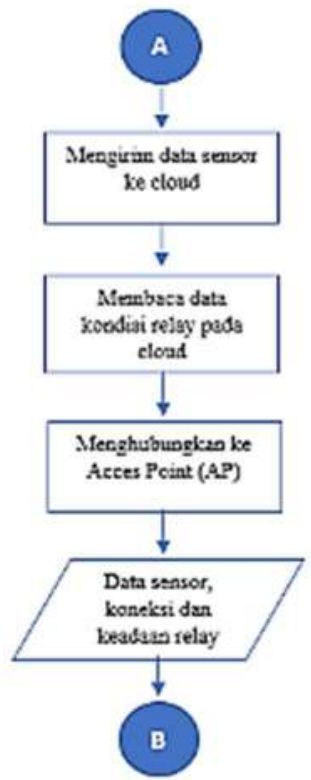

Gambar 2. Flowchart Komunikai Client dan Cloud
Berdasarkan Gambar 2, setelah aplikasi telah terkoneksi ke internet maka keempat NodeMCU client akan mengirimkan data sensor ke cloud. Pada sistem ini kami menggunakan real-time database sebagai tempat penyimpanan database di firebase.

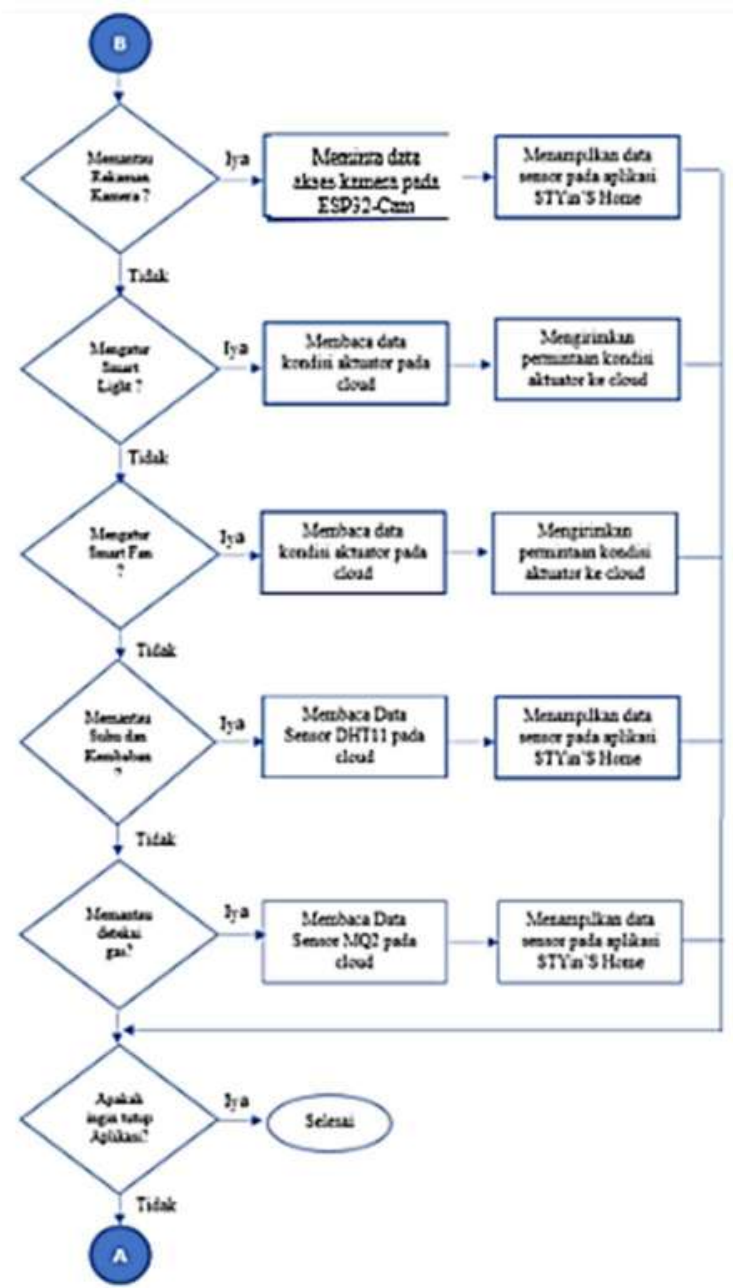

Gambar 3. Flowchart Aplikasi Styin's Home dengan Komunikasi Cloud dan Nodemcu Client

Berdasarkan Gambar 3 masukkan berupa data sensor, koneksi dan keadaan relay, selanjutnya pada sistem styins home memiliki 4 fitur utama yaitu rekaman kamera, smart light, smart fan dan deteksi gas. Dimana fungsi streaming kamera pada ESP32cam secara otomatis meminta akses data untuk memperoleh output menampilkan hasil streaming kamera sedangkan memantau smart light, suhu dan kelembaban pada smart fan dan deteksi gas kemudian aplikasi akan membaca data sensor yang ada pada 
Jurnal ECOTIPE, Vol. 7, No.2, Oktober 2020, Hal. 117-126

p-ISSN 2355-5068, e-ISSN 2622-4852

Akreditasi Kemenristekdikti (SINTA 4), SK. No.10/E/KPT/2019

DOI: 10.33019/jurnalecotipe.v7i2.1892

database cloud untuk memperoleh output menampilkan data sensor pada aplikasi.

\section{B. Perhitungan Throughput}

Perhitungan Throughput berfungsi untuk mengetahui nilai kecepatan jaringan pengiriman data yang aktual dengan jumlah paket data yang diterima oleh firebase dari nodeMCU client dan dari firebase ke aplikasi styins home sebagai tujuan info data dengan menggunakan durasi interval waktu selama $<2$ menit. Biasanya throughput merupakan kemampuan sebenarnya suatu jaringan dalam melakukan pengiriman data [12] [13] [14]. Menghitung Throughput sebagai berikut:

$$
\text { Throughput }=\frac{\text { Packet data yang diterima }}{\text { Lama pengamatan }}
$$

Tabel 1. Nilai Standar Throughtput (Sumber: TIPHON)

\begin{tabular}{|c|c|c|}
\hline Kategori Throughtptit & Indeks & Throughptit \\
\hline Sangat Bagus & $76 \%-100 \%$ & 4 \\
\hline Bagus & $51 \%-75 \%$ & 3 \\
\hline Sedang & $26 \%-50 \%$ & 2 \\
\hline Bunk & $<25 \%$ & 1 \\
\hline
\end{tabular}

\section{Perhitungan Delay}

Perhitungan Delay berfungsi untuk menentukan berapa lama waktu yang dibutuhkan oleh data NodeESP32-cam untuk sampai ke tempat tujuan data yaitu firebase dan IP 192.168.43.107 kemudian mengirimkan data ke aplikasi styins home menggunakan jaringan wifi yang dibatasi bandwidthnya [12] [13] [14]. Menghitung delay sebagai berikut:

$$
\text { Rata-rata delay }=\frac{\text { Total Delay }}{\text { Packet Yang Dterima }}
$$

Tabel 2. Nilai Standar Delay

\begin{tabular}{|c|c|c|}
\hline Kategori Deiay & Besar Delay & Indeks \\
\hline Sangat Bagus & $<150 \mathrm{~ms}$ & 4 \\
\hline Bagus & 150 sid $300 \mathrm{~ms}$ & 3 \\
\hline Sedang & 300 sid $450 \mathrm{~ms}$ & 2 \\
\hline Buruk & $>450 \mathrm{~ms}$ & 1 \\
\hline
\end{tabular}

\section{HASIL PENELITIAN DAN PEMBAHASAN}

Hasil implementasi aplikasi styins home dengan real-time database firebase. Membangun aplikasi styins home memanfaatkan firebase sebagai pengelola database dan software android studio sebagai platform untuk menjalankan aplikasi dalam smartphone.

A. Implementasi Tampilan Halaman Login

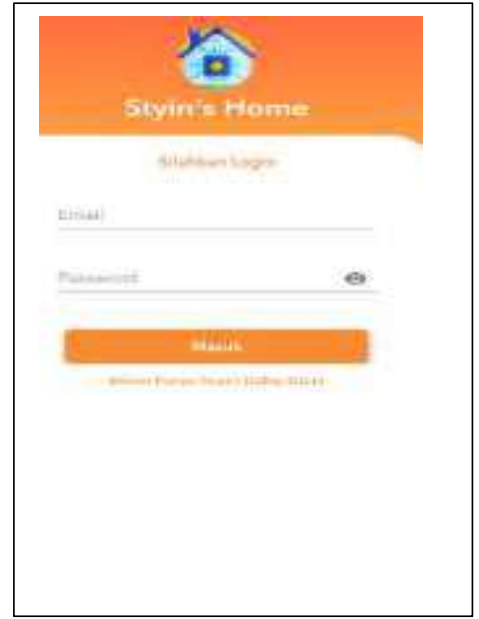

Gambar 4. Implementasi Tampilan Halaman Login

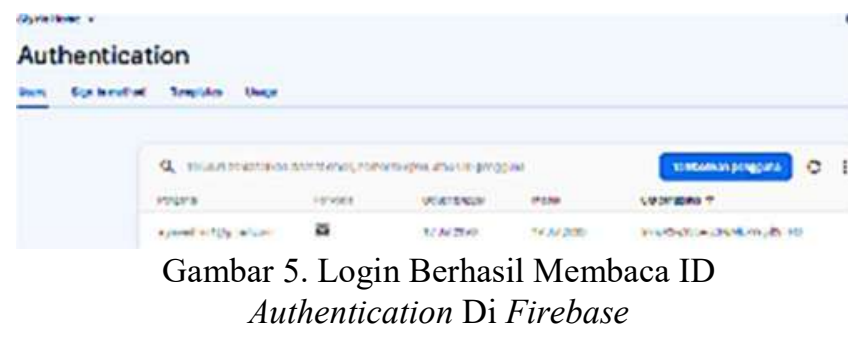

Pada Gambar 4 bahwa halaman ini berfungsi untuk memastikan bahwa pengguna telah terdaftar pada sistem dan membaca kode ID di authentication firebase seperti pada Gambar 5. Pada tampilan halaman login berisikan email dan password sebagai sistem keamanan akun user. 
Jurnal ECOTIPE, Vol. 7, No.2, Oktober 2020, Hal. 117-126

p-ISSN 2355-5068, e-ISSN 2622-4852

Akreditasi Kemenristekdikti (SINTA 4), SK. No.10/E/KPT/2019

DOI: 10.33019/jurnalecotipe.v7i2.1892

\section{B. Implementasi Tampilan Halaman Registrasi}

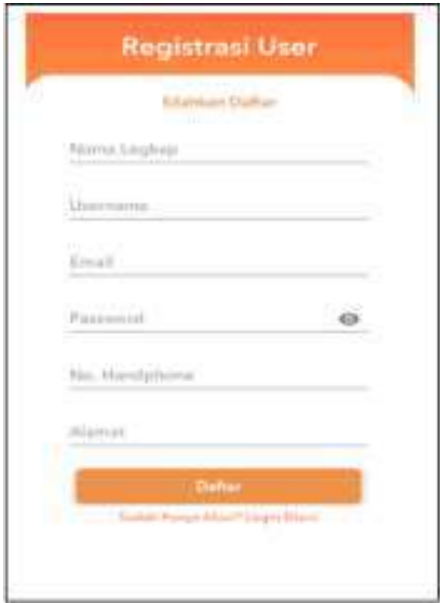

Gambar 6. Implementasi Halaman Registrasi

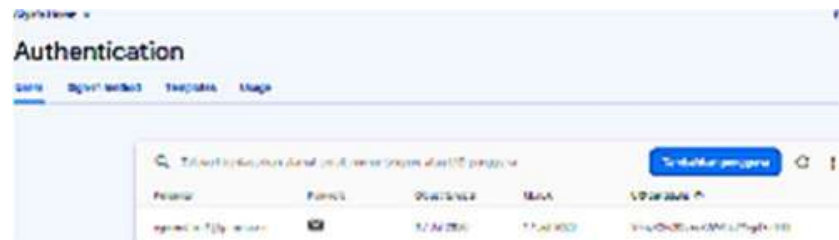

Gambar 7. Registrasi Berhasil di Authentication Firebase

Pada Gambar 6 merupakan sebuah halaman yang berfungsi untuk pengguna melakukan registrasi pendaftaran akun pengguna aplikasi styins home dan memberikan ID authentication sebagai pengenal dalam memasuki aplikasi terlihat pada Gambar 7.

\section{Implementasi Tampilan Halaman Dashboard}

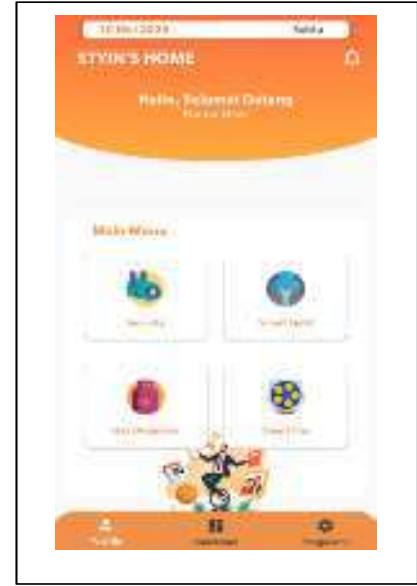

Gambar 8. Implementasi Halaman Dashboard

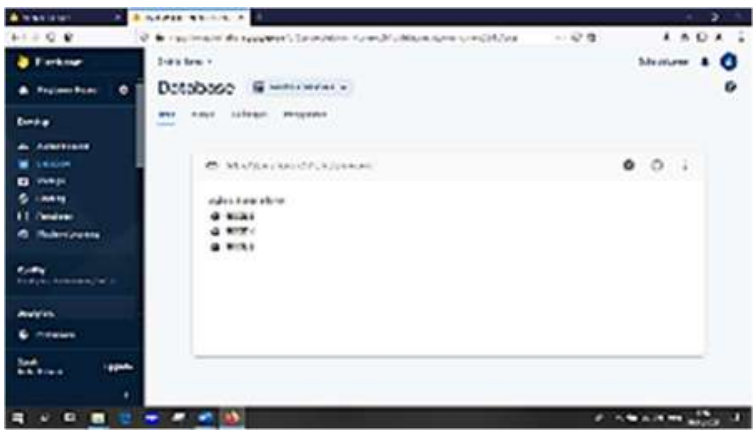

Gambar 9. Tampilan Real-time Database Firebase

Gambar 8 bahwa halaman ini akan ditampilkan oleh sistem jika user telah berhasil login kedalam sistem. Gambar 9 merupakan tampilan real-time database firebase yang akan membaca dan menerima pengiriman data dari NodeMCU. Halaman ini merupakan halaman utama yang menampilkan menumenu yang dapat diakses oleh user berisikan menu security yang rekaman kamera, smart light, smart fan dan gas detection.

\section{Implementasi Tampilan Halaman Menu Security}

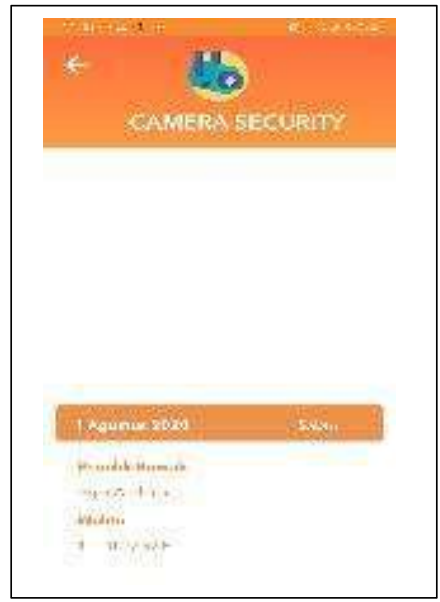

Gambar 10. Implementasi Halaman Menu Security
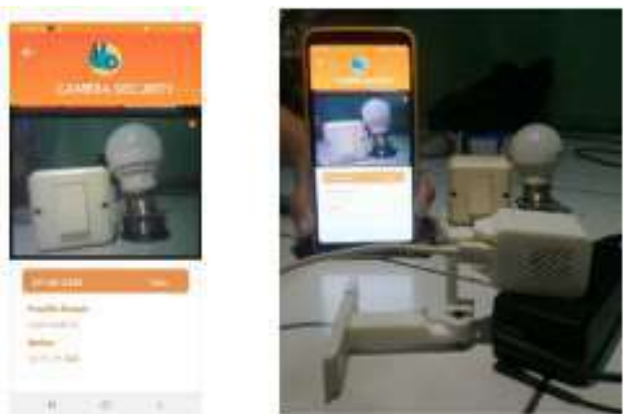

Gambar 11. Implementasi Menu security dan ESP32-Cam 
Jurnal ECOTIPE, Vol. 7, No.2, Oktober 2020, Hal. 117-126

p-ISSN 2355-5068, e-ISSN 2622-4852

Akreditasi Kemenristekdikti (SINTA 4), SK. No.10/E/KPT/2019

DOI: 10.33019/jurnalecotipe.v7i2.1892

Gambar 11 Menu security ini berfungsi melihat kondisi rumah secara siaran langsung dimana user dapat melihat melalui aplikasi styins home. Terlihat jelas pada Gambar 12 Menampilkan data security berupa hasil rekaman streaming.

\section{E. Implementasi Tampilan Halaman Menu Smart Light}

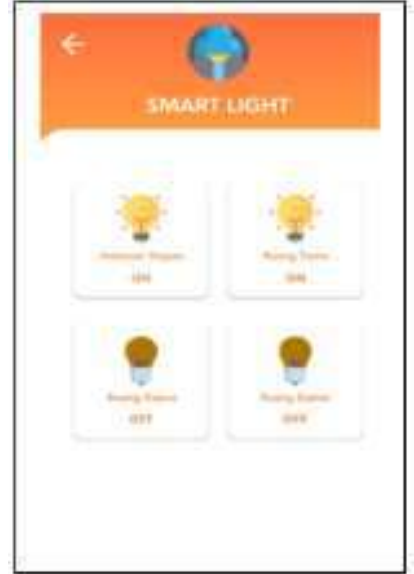

Gambar 12. Implementasi Halaman Menu Smart Light

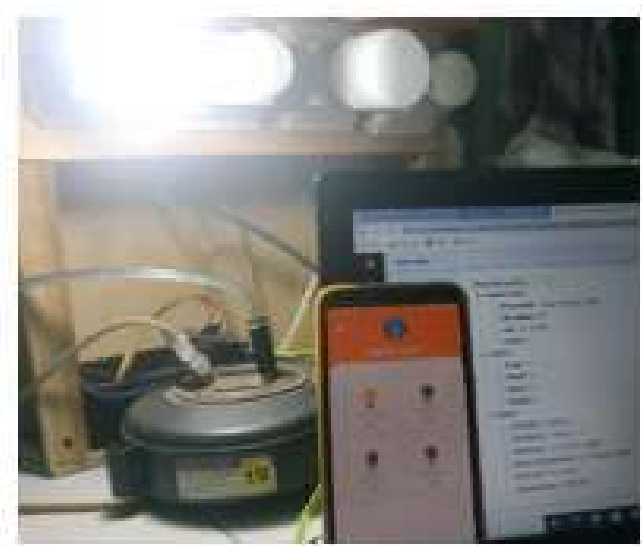

Gambar 13. Hasil Pengujian Fungsional Smart Light Menghidupkan Lampu 1

Berdasarkan Gambar 12 merupakan salah satu menu utama dalam aplikasi styins home. Pada halaman ini berisikan 4 list lampu yang berfungsi user dapat mengontrol lampu dengan cara menyalakan dan mematikan lampu dengan cara klik tombol pada lampu yang akan user atur dalam penggunaan seperti Gambar 13 dalam menghidupkan lampu depan.

\section{F. Implementasi Tampilan Halaman Menu Smart Fan}

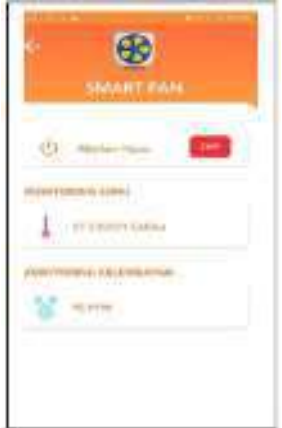

Gambar 14. Implementasi Tampilan Halaman Menu Smart Fan

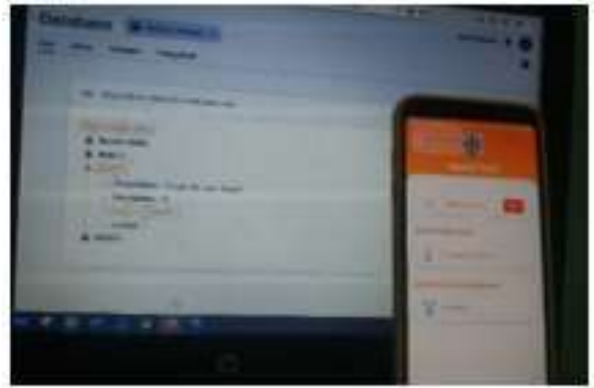

Gambar 15. Hasil Pengujian Fungsional Smart

Berdashthaat Kecematan Normal/dMediumplementasi halaman menu smart fan menampilkan tombol menyalakan dan mematikan smart fan menampilkan tampilan kadar suhu dalam satuan celcius sedangkan tampilkan kadar kelembaban menampilkan dalam satuan RH terlihat juga pada Gambar 15 menghasilkan suhu rentang $>23$ s/d 28 sehingga menghasilkan kecepatan normal/ medium.

\section{G. Implementasi Tampilan Halaman Menu}

Detection Gas

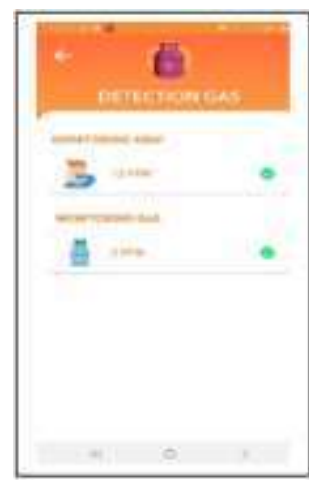

Gambar 16. Implementasi Tampilan Halaman Menu Detection Gas Saat Keadaan Aman 
Jurnal ECOTIPE, Vol. 7, No.2, Oktober 2020, Hal. 117-126

p-ISSN 2355-5068, e-ISSN 2622-4852

Akreditasi Kemenristekdikti (SINTA 4), SK. No.10/E/KPT/2019

DOI: 10.33019/jurnalecotipe.v7i2.1892

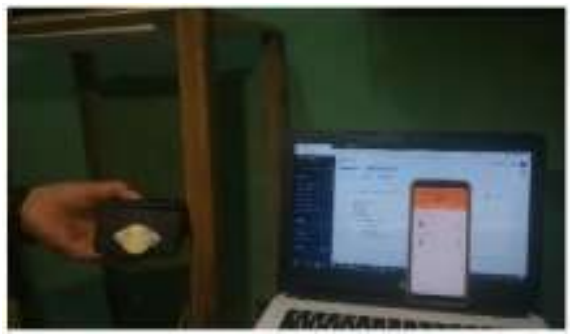

Gambar 17. Hasil Pengujian Fungsional Detection Gas Saat Keadaan Aman

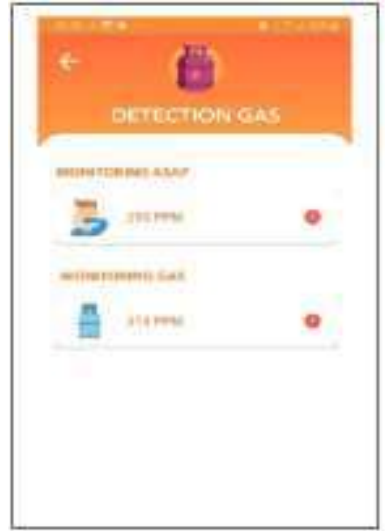

Gambar 18. Implementasi Tampilan Halaman Menu Detection Gas Saat Keadaan Bahaya

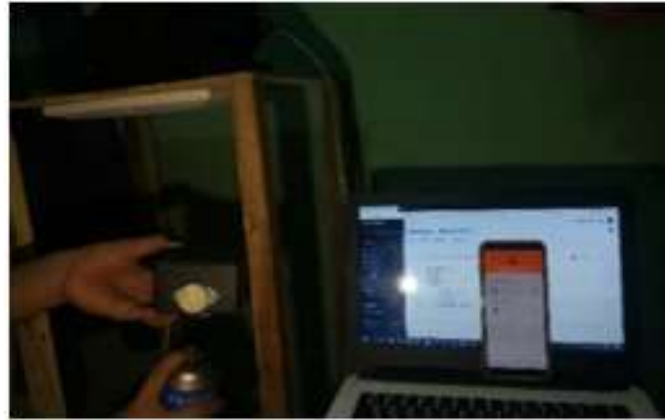

Gambar 19. Hasil Pengujian Fungsional Detection Gas Saat Keadaan Bahaya

Berdasarkan Gambar 18 dan Gambar 19 pada implementasi halaman menu detection gas menampilkan tampilan kadar asap yang terdeteksi sebelumnya pada NodeMCU dalam keadaan aman sedangkan berdasarkan Gambar 18 dan Gambar 19 menampilkan kadar gas asap dalam keadaan bahaya karena dalam pengaturan pada NodeMCU Ketika kadar gas >300 PPM dan kadar asap >200 PPM maka buzzer dan exhaust fan akan menyala serta diberikan notifikasi melalui aplikasi styins home.
Selain implementasi aplikasi styins home di realtime database firebase, terdapat pengujian throughput dan pengujian delay untuk mengetahui kualitas layanan aplikasi styins home dalam jaringan internet sesuai dengan fungsinya.

Tabel 3. Data Delay Smart light, Smart Fan dan Detection Gas Di Firebase

\begin{tabular}{|c|c|c|c|c|c|c|}
\hline \multirow{2}{*}{$\begin{array}{c}\text { Pengujian } \\
\mathrm{ke}\end{array}$} & \multicolumn{2}{|c|}{ Waktu } & \multirow{2}{*}{$\begin{array}{c}\text { Alokasi } \\
\text { Bandwith } \\
\text { (abps) }\end{array}$} & \multirow{2}{*}{$\begin{array}{l}\text { Total } \\
\text { Delay } \\
\text { (s) }\end{array}$} & \multirow{2}{*}{$\begin{array}{l}\text { Packet yang } \\
\text { diterima }\end{array}$} & \multirow{2}{*}{$\begin{array}{l}\text { Delay } \\
\text { (ms) }\end{array}$} \\
\hline & Tanggal & Jam & & & & \\
\hline 1 & $23 / 07 / 2020$ & $14: 50 \mathrm{~s} / \mathrm{d} 14: 52$ & 240 & 104,142 & 1509 & 69,01 \\
\hline 2 & $24 / 07 / 2020$ & $10: 55$ s/d $10: 57$ & 240 & 104,791 & 1575 & 66,53 \\
\hline 3 & $24 / 07 / 2020$ & $18: 44 \& / d 18: 46$ & 240 & 112,912 & 1608 & 70,21 \\
\hline 4 & $28 / 07 / 2020$ & $16: 16 \mathrm{~s} / \mathrm{d} 16: 18$ & 240 & 112,456 & 1528 & 73,59 \\
\hline \multicolumn{6}{|c|}{ Rata - rata delav (ms) } & 69,83 \\
\hline 5 & $24 / 07 / 2020$ & $18: 30 s / d$ 18:32 & 80 & 112,760 & 528 & 213,56 \\
\hline 6 & $25 / 07 / 2020$ & $02: 39 \approx / d 02: 41$ & 80 & 108,747 & 639 & 170,18 \\
\hline 7 & $25 / 07 / 2020$ & $03: 39 \mathrm{~s} / \mathrm{d} 03: 41$ & 80 & 106,352 & 484 & 219,73 \\
\hline 8 & $28 / 07 / 2020$ & $22: 08 s / d 22: 10$ & 80 & 113,872 & 592 & 192,35 \\
\hline \multicolumn{6}{|c|}{ Rata - rata delay (ms) } & 19895 \\
\hline 9 & $23 / 07 / 2020$ & $23: 41 \mathrm{~s} / \mathrm{d} 23: 43$ & 32 & 111,126 & 234 & 474,89 \\
\hline 10 & $24 / 07 / 2020$ & $22: 55: / d 22: 57$ & 32 & 111,980 & 294 & 380,88 \\
\hline 11 & $25 / 07 / 2020$ & $04: 49 \mathrm{~s} / \mathrm{d}$ 04:51 & 32 & 118,045 & 299 & 394,79 \\
\hline 12 & $28 / 07 / 2020$ & $22: 33 \mathrm{~s} / \mathrm{d} 22: 35$ & 32 & 103,903 & 231 & 449,79 \\
\hline \multicolumn{6}{|c|}{ Rata - rata delay (ms) } & 425,08 \\
\hline & & & & Nil: & delav tertinggi & 425.08 \\
\hline
\end{tabular}

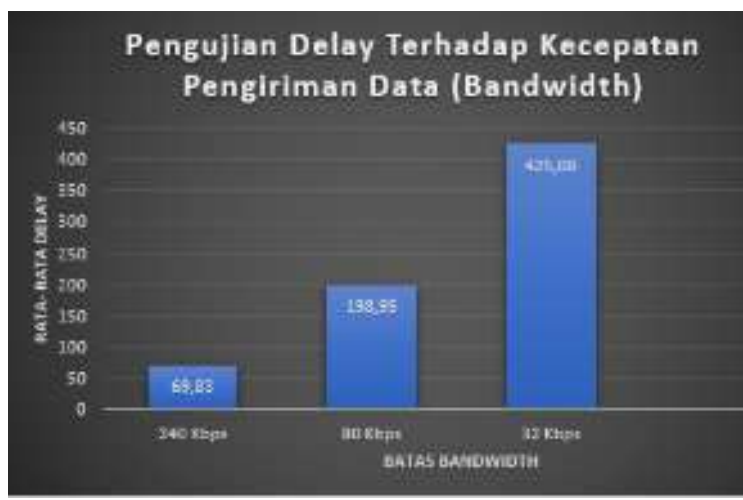

Gambar 20. Grafik Pengujian Delay Data Smart light, Smart Fan dan Detection Gas

Berdasarkan data dari Tabel 3 dan Gambar 20 disimpulkan bahwa semakin nilai delay mengalami penurunan maka semakin besar pula kecepatan pengiriman data jaringan. Kualitas jaringan pada nilai delay tertinggi untuk smart light, smart fan dan detection gas di firebase yaitu 425,08 ms memiliki kategori sedang dengan kecepatan pengiriman data 32 kbps dan nilai delay terendah yaitu 69,83 ms kategori 
Jurnal ECOTIPE, Vol. 7, No.2, Oktober 2020, Hal. 117-126

p-ISSN 2355-5068, e-ISSN 2622-4852

Akreditasi Kemenristekdikti (SINTA 4), SK. No.10/E/KPT/2019

DOI: 10.33019/jurnalecotipe.v7i2.1892

sangat bagus dengan kecepatan pengiriman data 240 kbps.

Tabel 4. Data Pengujian Throughput Dalam Penggunaan Smart Light, Smart Fan dan Detection Gas Di Firebase

\begin{tabular}{|c|c|c|c|c|c|c|c|}
\hline \multirow{2}{*}{$\begin{array}{c}\text { Perouglan } \\
\text { Ket }\end{array}$} & \multicolumn{2}{|c|}{ Walnu } & \multirow{2}{*}{ 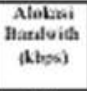 } & \multirow{2}{*}{$\begin{array}{l}\text { Pikes data } \\
\text { yang } \\
\text { dittrina } \\
\text { foylts) }\end{array}$} & \multirow{2}{*}{$\begin{array}{l}\text { Lañ } \\
\text { Pezęanation } \\
\text { (s) }\end{array}$} & \multirow{2}{*}{$\begin{array}{c}\text { Trouthprat } \\
\text { (Klipes) }\end{array}$} & \multirow{2}{*}{$\begin{array}{c}\% \\
\text { Troudhrot }\end{array}$} \\
\hline & Tankent & $2 \sin$ & & & & & \\
\hline$T$ & $\begin{array}{c}230071 \\
2020\end{array}$ & $\begin{array}{c}1450 \times 0 \\
1452\end{array}$ & 240 & 552503 & 104.142 & $\sqrt{2,4}$ & \multirow{5}{*}{1,47} \\
\hline 2 & $\begin{array}{c}24077 \\
2020\end{array}$ & $\begin{array}{c}10.55 .50 \\
1057\end{array}$ & 240 & मकलि & 104,791 & 33,65 & \\
\hline 3 & $\begin{array}{c}24.027 \\
2020\end{array}$ & $\begin{array}{c}18 \times 4 \times 40 \\
15.46\end{array}$ & 240 & 495277 & 112912 & 35,00 & \\
\hline 4 & $\begin{array}{l}25077 \\
2020\end{array}$ & $\begin{array}{c}16: 16.80 \\
16: 18\end{array}$ & 240 & 430005 & 112456 & 30,84 & \\
\hline \multicolumn{6}{|c|}{ 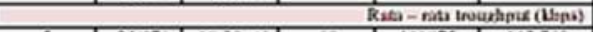 } & 35.50 & \\
\hline 5 & $\begin{array}{l}24078 \\
2020\end{array}$ & $\begin{array}{l}18: 10: 40 \\
15: 32\end{array}$ & 58 & $111 \times 75$ & 112.760 & 9939 & \multirow{5}{*}{1,00} \\
\hline 6 & $\begin{array}{l}25.077 \\
2020\end{array}$ & $\begin{array}{c}02: 99 \times 4 \\
0241\end{array}$ & 50 & $13 \% 050$ & Tok.247 & 10,652 & \\
\hline 7 & $\begin{array}{l}25.077 \\
2020\end{array}$ & $\begin{array}{c}03.39 \times 4 \\
0341\end{array}$ & 50 & 9016 & 106.352 & 9,460 & \\
\hline $\mathbf{8}$ & $\begin{array}{l}28^{\prime} 077 \\
2020\end{array}$ & $\begin{array}{c}22,00 \times 10 \\
22: 10\end{array}$ & 50 & 9657 & $113 \times 72$ & 6.64 & \\
\hline \multicolumn{6}{|c|}{ 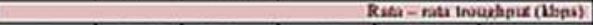 } & 2.025 & \\
\hline 9 & $\begin{array}{c}21 \% 07 \% \\
2020\end{array}$ & $\begin{array}{c}23,41 \times 40 \\
23.43\end{array}$ & 32 & $2352 \mathrm{~B}$ & 114,126 & 1.565 & \multirow{5}{*}{$0,7 i$} \\
\hline 10 & $\begin{array}{c}24077 \\
2020\end{array}$ & $\begin{array}{c}22: 55: 04 \\
22.57\end{array}$ & $\sqrt{2}$ & 41320 & 111950 & 2.965 & \\
\hline 11 & $\begin{array}{l}25027 \\
2020\end{array}$ & $\begin{array}{l}04.60 \times 19 \\
04.51\end{array}$ & 32 & $5605 \mathrm{~s}$ & IIRous & 3 , 650 & \\
\hline 12 & $\begin{array}{l}2 K^{\prime} 072 \\
2020\end{array}$ & $\begin{array}{l}22: 0 \times 19 \\
22: 15\end{array}$ & 32 & 25092 & In:Pas & 6,747 & \\
\hline \multicolumn{6}{|c|}{ 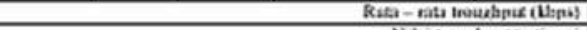 } & 2505 & \\
\hline \multirow{2}{*}{\multicolumn{6}{|c|}{ 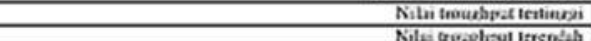 }} & 35.59 & 1.47 \\
\hline & & & & & & 2 Sos & 0.78 \\
\hline
\end{tabular}

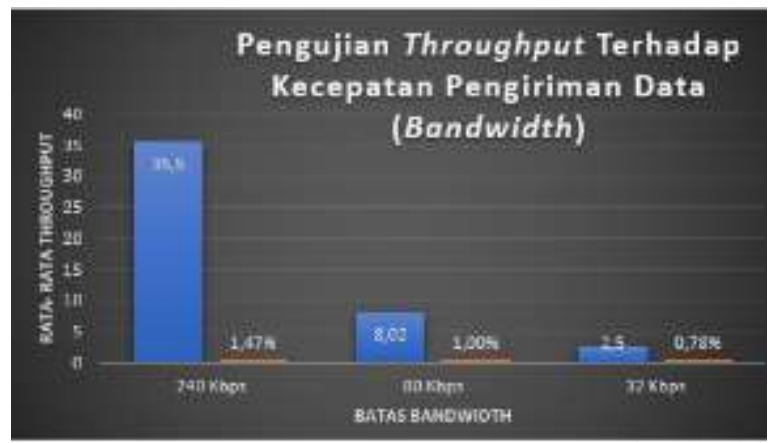

Gambar 21. Grafik Pengujian Throughput Data Smart light, Smart Fan dan Detection Gas

Berdasarkan data dari Tabel 4 dan Gambar 21 disimpulkan bahwa semakin nilai throughput mengalami kenaikan maka semakin besar pula kecepatan pengiriman data jaringan. Dimana kualitas jaringan pada nilai throughput tertinggi untuk smart light, smart fan dan detection gas di firebase yaitu 35,5 kbps dengan persen throughput 1,47 \% memiliki kategori buruk menggunakan kecepatan pengiriman data $240 \mathrm{kbps}$ dan nilai throughput terendah yaitu 0,78 kbps dengan persen throughput 2,5\% kategori buruk menggunakan kecepatan pengiriman data $32 \mathrm{kbps}$.
Tabel 5. Data Delay Pada Streaming Kamera Di IP 192.168.43.107

\begin{tabular}{|c|c|c|c|c|c|c|}
\hline \multirow{2}{*}{$\begin{array}{c}\text { Retrujian } \\
\mathbf{k e}\end{array}$} & \multicolumn{2}{|c|}{ WzLtu } & \multirow{2}{*}{ 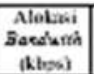 } & \multirow{2}{*}{$\begin{array}{c}\text { Tats! } \\
\text { Delay } \\
\text { (s) }\end{array}$} & \multirow{2}{*}{\begin{tabular}{c|} 
Pucker ying \\
citerima
\end{tabular}} & \multirow{2}{*}{$\begin{array}{l}\text { Delay } \\
\text { (mis) }\end{array}$} \\
\hline & Tanoul & $20 \mathrm{n}$ & & & & \\
\hline$T$ & $0805 / 2020$ & $12: 53 \times 412: 55$ & 240 & 105.937 & 11748 & 9,01 \\
\hline 2 & $0001 / 2020$ & $13: 21 \times 013: 23$ & 240 & $109.19 \mathrm{k}$ & $15 \%$ & 6,52 \\
\hline 3 & $0201 / 2020$ & $14: 55 \times 211.57$ & 240 & 711.147 & 23219 & 4,78 \\
\hline 4 & $0001 / 2020$ & $19.14 \times 418.16$ & 240 & $108 \cdot 156$ & 15ाण & 7,18 \\
\hline \multicolumn{6}{|c|}{ Rats - nta delav (ns) } & 7,105 \\
\hline 3 & $0 \times 0 \times 2020$ & 13:15s:413:17 & 50 & 119472 & 1904 & 66,94 \\
\hline 6 & $0005 / 2020$ & $15: 10 \times 1115: 12$ & 5 & 117531 & 1650 & 72.55 \\
\hline 7 & 030522020 & $16.32 \times 1416.34$ & 58 & 716,352 & 1550 & 76,54 \\
\hline 8 & $0802 / 2020$ & $2000 \times 420.10$ & 50 & 816.172 & 1498 & 7735 \\
\hline \multicolumn{6}{|c|}{ Rats - natia delav (tas) } & 73,39 \\
\hline 9 & $00 / 02 / 2020$ & $13: 40 \times 413.42$ & 32 & $110 \times 27$ & 435 & $24.2 \mathrm{~K}$ \\
\hline 10 & $0804 / 2020$ & $14: 25 \times 414.27$ & 32 & 713.209 & 585 & 19l]18 \\
\hline II & $0005 / 2020$ & 15:50 s/d15:22 & 32 & IIS045 & 695 & $162 \times 2$ \\
\hline 12 & $0001 / 2020$ & 21:02xd21:a4 & 32 & IISnas & 674 & 17062 \\
\hline \multicolumn{6}{|c|}{ Rata-nitardelay (tas) } & 193,025 \\
\hline \multicolumn{6}{|c|}{ Nilai driav itritage } & 193,025 \\
\hline
\end{tabular}

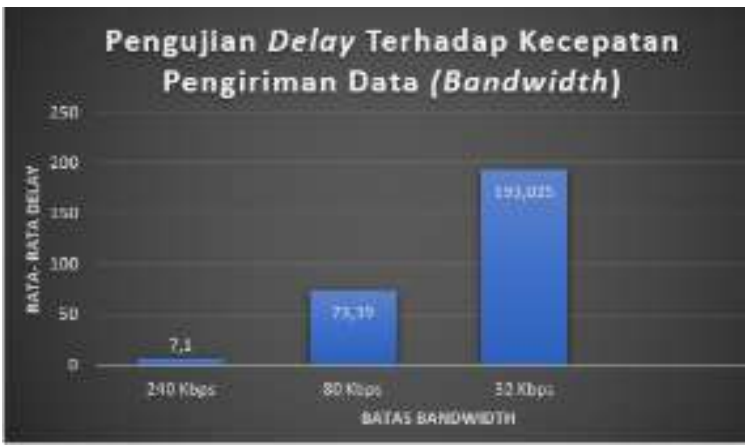

Gambar 22. Grafik Pengujian Delay Data Security Terhadap Kecepatan Pengiriman Data Jaringan

Berdasarkan data dari Tabel 5 dan Gambar 22 disimpulkan bahwa semakin nilai delay mengalami penurunan maka semakin besar pula kecepatan pengiriman data jaringan. Kualitas jaringan pada nilai delay tertinggi untuk untuk streaming kamera yaitu 193,02 ms kategori bagus dengan kecepatan pengiriman data $32 \mathrm{kbps}$ dan nilai delay terendah yaitu 7,1 ms kategori sangat bagus dengan kecepatan pengiriman data $240 \mathrm{kbps}$. 
Jurnal ECOTIPE, Vol. 7, No.2, Oktober 2020, Hal. 117-126

p-ISSN 2355-5068, e-ISSN 2622-4852

Akreditasi Kemenristekdikti (SINTA 4), SK. No.10/E/KPT/2019

DOI: 10.33019/jurnalecotipe.v7i2.1892

Tabel 6. Data Pengujian Throughput Streaming Kamera Di IP 192.168.43.107

\begin{tabular}{|c|c|c|c|c|c|c|c|}
\hline \multirow{2}{*}{$\begin{array}{c}\text { Peruugian } \\
\mathrm{ke}\end{array}$} & \multicolumn{2}{|c|}{ W2Llu } & \multirow{2}{*}{ 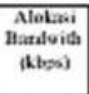 } & \multirow{2}{*}{$\begin{array}{l}\text { Patal dats } \\
\text { yang } \\
\text { ditcrina } \\
\text { (bstesa) }\end{array}$} & \multirow{2}{*}{$\begin{array}{c}\text { Lanta } \\
\text { Petginutax } \\
\text { (b) }\end{array}$} & \multirow{2}{*}{ 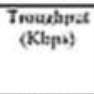 } & \multirow{2}{*}{$\begin{array}{c}4 \\
\text { Troughpot }\end{array}$} \\
\hline & Tanceal & Jatn & & & & & \\
\hline$T$ & $\begin{array}{c}030 \times \\
2020\end{array}$ & $\begin{array}{c}12: 53 \times 4 \\
12: 55\end{array}$ & 240 & 10170050 & 105.957 & 708.18 & \multirow{5}{*}{$+0,00$} \\
\hline 2 & $\begin{array}{c}0 \times 0 x^{\prime} \\
2020\end{array}$ & $\begin{array}{c}13: 21 \times 1 \\
13: 21\end{array}$ & 240 & 13784345 & 109.195 & 1009,56 & \\
\hline 3 & $\begin{array}{c}0208 \\
2020\end{array}$ & $\begin{array}{c}\text { 14:S5 s:1 } \\
14: 57\end{array}$ & 240 & 1512115! & 111.147 & $10 \sigma x, 37$ & \\
\hline 4 & $\begin{array}{c}500 x^{\prime} \\
2020\end{array}$ & $\begin{array}{l}19: 14 \times 11 \\
19: 16\end{array}$ & 240 & 1397252 & TOKASG & 1030,55 & \\
\hline \multicolumn{6}{|c|}{ 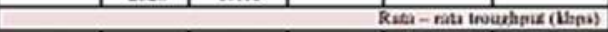 } & 99.29 & \\
\hline 5 & $\begin{array}{c}0 y 0 x \\
2020\end{array}$ & $\begin{array}{c}\text { 13:15:41 } \\
23: 17\end{array}$ & 50 & 2411516 & 119.472 & 16ात? & \multirow{5}{*}{15.10} \\
\hline 6 & $\begin{array}{c}050 x^{\prime} \\
2020\end{array}$ & $\begin{array}{c}15: 10 \times 41 \\
15: 12\end{array}$ & 50 & 1230505 & $117.53 !$ & 03,76 & \\
\hline 7 & $\begin{array}{c}0908 \\
2020\end{array}$ & $\begin{array}{c}16: 32 \times 11 \\
16: 4\end{array}$ & 50 & 1414375 & 117.999 & 85,50 & \\
\hline$\overline{8}$ & $\begin{array}{c}0908 \\
2030\end{array}$ & $\begin{array}{c}50.05 \times 41 \\
20: 10\end{array}$ & 50 & $211 \mathrm{~m}$ & 119.174 & 142,24 & \\
\hline \multicolumn{6}{|c|}{ 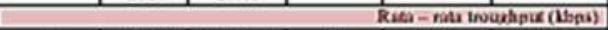 } & 120,54 & \\
\hline 9 & $\begin{array}{c}090 \times 1 \\
2020\end{array}$ & $\begin{array}{c}13: 40 \times 4 d \\
13: 42\end{array}$ & 32 & 346593 & 11ax27 & 25,01 & \multirow{5}{*}{20,22} \\
\hline 10 & $\begin{array}{c}0 \times 08 \\
2020\end{array}$ & $\begin{array}{c}14: 25 \times 1 \\
14: 27\end{array}$ & 32 & 155742 & $113.70 \%$ & 32,05 & \\
\hline II & $\begin{array}{c}0308 \\
2020\end{array}$ & $\begin{array}{c}15: 20 \times d \mathrm{~d} \\
15: 22\end{array}$ & 32 & 557681 & 11504 & 38,76 & \\
\hline 12 & $\begin{array}{c}0908 \\
2020\end{array}$ & $\begin{array}{c}2102 \times 1 / 21 \\
21: 94\end{array}$ & 32 & $504 \pi 51$ & 115000 & 35,10 & \\
\hline \multicolumn{6}{|c|}{ 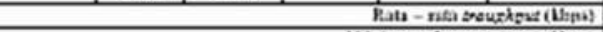 } & 32,72 & \\
\hline \multirow{2}{*}{\multicolumn{6}{|c|}{ 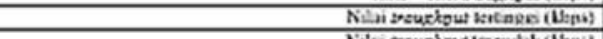 }} & 451.52 & 40,50 \\
\hline \multicolumn{5}{|c|}{ 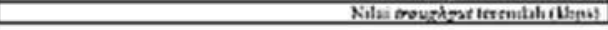 } & & Q $2 ., k 2$ & 10.22 \\
\hline
\end{tabular}

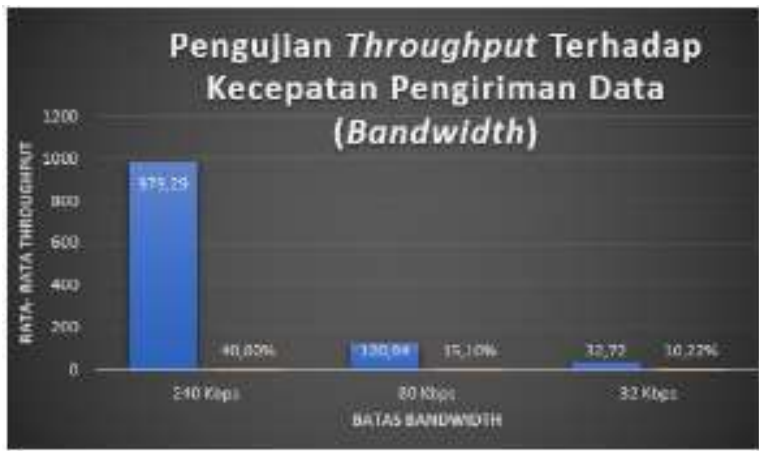

Gambar 23. Grafik Pengujian Throughput Data Streaming Kamera Terhadap Kecepatan Pengiriman Data Jaringan

Berdasarkan data dari Tabel 6 dan Gambar 23 disimpulkan bahwa semakin nilai throughput mengalami kenaikan maka semakin besar pula kecepatan pengiriman data jaringan. Dimana kualitas jaringan pada nilai throughput tertinggi untuk streaming kamera yaitu 979,29 kbps dengan persen throughput $40,80 \%$ memiliki kategori sedang menggunakan kecepatan pengiriman data $240 \mathrm{kbps}$ dan nilai throughput terendah yaitu $32,72 \mathrm{kbps}$ dengan persen throughput 10,22\% kategori buruk menggunakan kecepatan pengiriman data $32 \mathrm{kbps}$.

\section{KESIMPULAN}

Aplikasi styins home berhasil menampilkan halaman login dan registrasi, hasil streaming kamera, kondisi smart light dan dapat mengoperasikanya, data suhu dan kelembaban yang diletakkan di smart fan serta notifikasi kecepatan kipas dimana jika suhu $>28$ notifikasi kipas kecepatan high, $>23$ s/d 28 notifikasi suhu normal, $>20 \mathrm{~s} / \mathrm{d}<23$ notifikasi suhu low dan dapat menampilkan hasil data kadar gas dan asap beserta notifikasi bahaya jika kadar gas $>300$ PPM sedangkan kadar asap >200 PPM. Dengan hasil dari pengujian delay dimana semakin besar nilai bandwidth maka semakin nilai delay mengalami penurunan. Pada produk styins home memiliki nilai delay tertinggi pada smart light, smart fan dan detection gas di firebase yaitu 425,08 ms (sedang) dengan kecepatan pengiriman data $32 \mathrm{kbps}$ dan nilai delay terendah pada streaming kamera yaitu 7,1 ms (sangat bagus) dengan kecepatan pengiriman data $240 \mathrm{kbps}$. Hasil pengujian throughput dimana semakin besar nilai bandwidth maka semakin besar pula nilai persentasi throughput. Dimana nilai persentasi throughput tertinggi untuk smart light, smart fan dan detection gas di firebase yaitu 1,47\% (buruk) menggunakan bandwidth 240 kbps sedangkan nilai persentasi throughput terendah pada streaming kamera yaitu 40,80\% (sedang) menggunakan kecepatan pengiriman data $240 \mathrm{kbps}$.

\section{REFERENSI}

[1] K. Lampu, S. Wireless, and B. Arduino, "Smart Campus STMIK Sumedang ( Smart Classroom )."

[2] A. S. Mustaqim, D. Kurnianto, F. T. Syifa, and C. Author, "Implementasi Teknologi Internet of Things Pada Sistem Pemantauan Kebocoran Gas LPG dan Kebakaran Menggunakan Database Pada Google Firebase," vol. 12, no. April, 2020.

[3] A. Wijaya, Y. Saragih, and I. Lammada, "Yaiao Application Collecting Log File $R F \quad 4 G$ Android-Based Replacing Data Cables to Laptop on Traditional RF Drive Test Models," pp. 271-275, 2020.

[4] A. Kusumaningrum, A. Pujiastuti, and M. Zeny, "Pemanfaatan Internet of Things Pada Kendali Lampu," Compiler, vol. 6, no. 1, pp. 53-59, 2017, doi: 10.28989/compiler.v6i1.201. 
Jurnal ECOTIPE, Vol. 7, No.2, Oktober 2020, Hal. 117-126

p-ISSN 2355-5068, e-ISSN 2622-4852

Akreditasi Kemenristekdikti (SINTA 4), SK. No.10/E/KPT/2019

DOI: 10.33019/jurnalecotipe.v7i2.1892

[5] Tamplin J. (2018, April 17). Firebase Expends To Become A Unified App Platform. Retrieved fromhttps://firebase.googleblog.com/2016/05/ firebase-expands-to-become-unified-appplatform.html

[6] G. R. Paraya and R. Tanone, "Penerapan Firebase Realtime Database Pada Prototype Aplikasi Pemesanan Makanan Berbasis Android," J. Tek. Inform. dan Sist. Inf., vol. 4, no. 3, pp. 397-406, 2018, doi: 10.28932/jutisi.v4i3.870.

[7] I. P. Sari and S. Sukri, "Analisis Penerapan Metode Antrian Hirarchical Token Bucket untuk Management Bandwidth Jaringan Internet," J. RESTI (Rekayasa Sist. dan Teknol. Informasi), vol. 2, no. 2, pp. 522-529, 2018, doi: 10.29207/resti.v2i2.458.

[8] Y. Saragih, Ibrahim, and A. Elisabet, "Study of Smart Antenna Wide Band Multi Beam by Algorithm Switch Beam," J. Sustain. Eng. Proc. Ser., vol. 1, no. 2, pp. 247-257, 2019, doi: 10.35793/joseps.v1i2.37.

[9] A. Sharma, R. Kumar, and V. Mansotra, "Proposed Stemming Algorithm for Hindi Information Retrieval," Int. J. Innov. Res. Comput. Commun. Eng. (An ISO Certif. Organ., vol. 3297, no. 6 , pp. 11449-11455, 2016, doi: 10.15680/IJIRCCE.2016.

[10] Y. Mardiana and J. Sahputra, "Analisa Performansi Protokol TCP , UDP dan SCTP," J. Media Infotama, vol. 13, no. 2, pp. 73-84, 2017.

[11] R. Hidayat, R. A. Darajatun, R. Setiawan, and V. P. Fahrani, "Alat pengukur kecepatan lari berbasis mikrokontroler 1," vol. 4, no. 1, pp. 167-173, 2019.

[12] P. Sinyal, I. Berbasis, and I. R. U. G. Dqg, “1 ), 2), 3 )."

[13] A. Fauzi, "Analisis Kualitas Transmisi Data Pada E-Learning Streaming Multimedia Dengan Quality Of Service ( QoS )," Semin. Nas. Inov. Teknol., pp. 93-106, 2019.

[14] R. Wulandari, "Analisis QoS (Quality of Service) Pada Jaringan Internet (Studi Kasus : Upt Loka Uji Teknik Penambangan Jampang Kulon - LIPI)," J. Tek. Inform. dan Sist. Inf., vol. 2, no. 2, pp. 162-172, 2016, doi: 10.28932/jutisi.v2i2.454. 